\title{
Plant-Based Milks: Cashew ${ }^{1}$
}

\author{
Jamie Zeldman, Daniela Rivero-Medoza, and Wendy J. Dahl²
}

The availability and consumption of plant-based, also known as nondairy, milk alternatives have been on the rise. Sales of nondairy milk alternatives have more than doubled (Bridges 2018), whereas consumption of traditional cow's milk has dropped (Singhal et al. 2017). This increase may be due to plant-based milks being perceived as "natural," as well as a rise in veganism and avoidance of lactose (Schuster et al. 2018). The primary plant-based dairy alternatives are almond, soy, coconut, cashew, and rice. This publication discusses the nutritional content, potential health benefits, and potential risks of cashew milk.

\section{How is cashew milk made?}

Cashew, a tree nut, is the third most consumed tree nut in the United States (Mah et al. 2017). Cashew milk is made primarily from a blend of cashews and water. Other ingredients may include almonds, calcium carbonate, vitamins $\mathrm{E}$, A, and D2, salt, natural flavor, and lecithin (an emulsifier). Other ingredients, including sugar, are added if the milk is flavored.

To make cashew milk, the first step is to wash and dry the kernels. The cashew nuts are soaked in hot water to remove the hull, and then soaked again in cold deionized water. They are drained, rinsed, and wet-milled. The resulting slurry is filtered and pasteurized or treated at ultra-high temperature (UHT) for shelf stability (Manzoor et al. 2017). Lastly, other ingredients, such as gums, lecithin, and flavors, are added to thicken, emulsify, and enhance flavor, respectively (White n.d.).

\section{How does the nutrient profile of cashew milk compare to cow's milk?}

In general, fortified cow's milk is a good source of several essential nutrients, including protein, vitamin $\mathrm{D}$, calcium, vitamin A, and potassium (USDA 2015). Most plant-based milks, including cashew milk, are much lower in protein. Calcium and vitamins A and D are often added to cashew milk and other plant-based milks. Table 1 shows a comparison of unsweetened, unflavored cashew milk to fat-free, low-fat, and whole cow's milk.

Calories. A serving of whole cow's milk contains about 150 calories, and fat-free contains 83 calories, whereas a serving of cashew milk contains only about 25 calories (USDA 2015). Flavored and sweetened cashew milk is higher in calories.

Protein. A serving of cow's milk contains about 8 grams (g) of protein, whereas a serving of cashew milk contains less than $1 \mathrm{~g}$ of protein (USDA 2015).

Fat. A serving of whole milk contains about $8 \mathrm{~g}$ of fat, and about $5 \mathrm{~g}$ of the total fat is saturated fat. Low-fat cow's milk contains similar amounts of fat as cashew milk (Silk n.d., USDA 2015). However, a serving of cashew milk has $0 \mathrm{~g}$ saturated fat, compared to low-fat cow's milk, which has 1.5 g.

1. This document is FSHN20-51, one of a series of the Food Science and Human Nutrition Department, UF/IFAS Extension. Original publication date October 2020. Visit the EDIS website at https://edis.ifas.ufl.edu for the currently supported version of this publication.

2. Jamie Zeldman, graduate student, Food Science and Human Nutrition Department; Daniela Rivero-Mendoza, Extension and research coordinator; and Wendy J. Dahl, associate professor, Food Science and Human Nutrition Department; UF/IFAS Extension, Gainesville, FL 32611.

The Institute of Food and Agricultural Sciences (IFAS) is an Equal Opportunity Institution authorized to provide research, educational information and other services

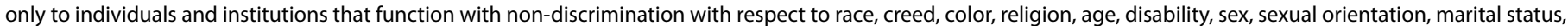

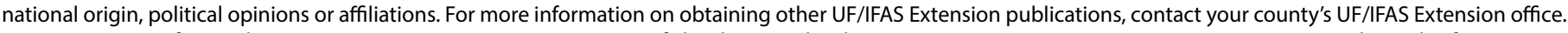
U.S. Department of Agriculture, UF/IFAS Extension Service, University of Florida, IFAS, Florida A \& M University Cooperative Extension Program, and Boards of County Commissioners Cooperating. Nick T. Place, dean for UF/IFAS Extension. 
Carbohydrates. A serving of cow's milk contains about $12 \mathrm{~g}$ of carbohydrate, almost all of which is in the form of the sugar lactose (USDA 2015). A serving of cashew milk contains about $1 \mathrm{~g}$ of carbohydrate and no sugar. Neither cow's milk nor cashew milk contains fiber.

Vitamins and Minerals. Prior to fortification with added nutrients, cashew milk provides less than $10 \%$ of the daily value of all nutrients, whereas cow's milk contains greater than $10 \%$ of the daily value for protein, calcium, vitamin B12, riboflavin, niacin, phosphorus, and pantothenic acid (Schuster et al. 2018). However, many brands of cashew milk contain comparable amounts of nutrients, such as vitamin A and vitamin D, and even higher amounts of calcium, due to fortification. Bioavailability, which is the amount of a nutrient that is absorbed and used by the body, may not be nutritionally equivalent to cow's milk (Singhal et al. 2017). The amount of sodium in some brands of cashew milk may be higher than that in cow's milk.

\section{What are the potential health benefits of cashew milk?}

One of the benefits of consuming cashew milk is that it may be a beverage option for people with allergies to cow's milk proteins or intolerance to lactose. However, for those people with lactose intolerance, lactose-free dairy milks are also available. Another possible benefit, for adults pursuing weight loss, is the fewer calories cashew milk provides compared to cow's milk, while providing comparable amounts of calcium, vitamin A, and vitamin D.

Similar to most other plant-based milks, cashew milk contains low levels of saturated fat, so consuming cashew milk is in line with the recommendations from USDA Dietary Guidelines for Americans, which states that saturated fats should provide less than $10 \%$ of calories consumed (USDA 2015). Cashews are abundant in monounsaturated fatty acids and polyunsaturated fatty acids, which are considered "good fats." A 1-cup serving of low-calorie cashew milk provides about $2 \mathrm{~g}$ of fat-less than $1 / 2$ teaspoon. The most abundant fatty acid in cashews is oleic acid (Soares et al. 2013). Diets high in oleic acid, such as the Mediterranean diet, have been shown to reduce cardiovascular disease risk (Mah et al. 2017). However, the amount of cashews in a serving of commercial cashew milk is very small-about 3 cashews per serving for the example cashew milk given in Table 1 . The potential health benefits of eating cashews might not be achieved from consuming cashew milk.

\section{What are the possible health risks of cashew milk?}

One risk of cashew milk is that it contains cashews and possibly almonds, which are food allergens that may cause severe symptoms and, in some cases, may be lifethreatening for certain allergic individuals (Food and Drug Administration [FDA] n.d.). Additionally, cashew milk's protein content is low, which may be a particular concern for certain groups, such as older adults and vegans, who may not consume sufficient protein. Consuming adequate protein is important because it builds and preserves muscle (Arentson-Lantz et al. 2015).

\section{Is cashew milk an appropriate choice for children?}

If the reason for choosing a plant-based milk alternative is to provide a "milk" nutritionally similar to cow's milk for growing children, cashew milk is not an appropriate substitute. Only soy milk is nutritionally similar to cow's milk (Schuster et al. 2018). A recent study found that children who consumed 3 cups of nondairy milk alternatives daily, compared to those who consumed 3 cups of cow's milk, displayed shorter stature, a difference which may be due to the lower protein intake (Morency et al. 2017). Cashew milk does provide more calcium than cow's milk, but the fortified micronutrients may not be nutritionally equivalent to cow's milk due to the differences in bioavailability, as described above (Singhal et al. 2017). Cow's milk and fortified soy milk are the most nutritionally appropriate choices for children. A health care provider, such as a registered dietitian nutritionist, can answer your questions related to plant-based milks and child growth.

\section{Conclusion}

As many consumers are opting for plant-based milks, either for perceived health benefits or personal preference, it is important to assess the nutritional profile in comparison to cow's milk. Unsweetened cashew milk is very low in protein, but if fortified, it may provide a source of calcium and vitamins $\mathrm{A}$ and $\mathrm{D}$ in a lower-calorie beverage. Cashew milk is not an appropriate milk replacement for growing children. 


\section{References}

Arentson-Lantz, Emily, Stephanie Clairmont, Douglas Paddon-Jones, Angelo Tremblay, and Rajavel Elango. 2015. "Protein: A Nutrient in Focus." Applied Physiology, Nutrition, and Metabolism 40 (8): 755-761. https://doi. org/10.1139/apnm-2014-0530

Bridges, Meagan. 2018. "Moo-Ove over, Cow's Milk: The Rise of Plant-Based Dairy Alternatives." Practical Gastroenterology 21. https://practicalgastro.com/wp-content/ uploads/2019/07/Moo-ove-Over-Cow-Milk-Rise-of-PlantBased-Dairy-Alternatives.pdf. Accessed 10 August 2020.

Food and Drug Administration (FDA). n.d. "Food Allergies: What You Need to Know.” https://www.fda.gov/Food/ ResourcesForYou/Consumers/ucm079311.htm. Accessed 10 August 2020.

Mah, Eunice, Jacqueline A. Schulz, Valerie N. Kaden, Andrea L. Lawless, Jose Rotor, Libertie B. Mantilla, and DeAnn J. Liska. 2017. "Cashew Consumption Reduces Total and LDL Cholesterol: A Randomized, Crossover, Controlled-Feeding Trial." The American Journal of Clinical Nutrition 105 (5): 1070-1078. https://doi.org/10.3945/ ajcn.116.150037

Manzoor, Muhammad Faisal, Ahsan Manzoor, Rabia Siddique, and Nazir Ahmad. 2017. "Nutritional and Sensory Properties of Cashew Seed (Anacardium Occidentale) Milk." Modern Concepts \& Developments in Agronomy 1 (1): 1-4. https://doi.org/10.31031/MCDA.2017.01.000501

Morency, Marie-Elssa, Catherine S. Birken, Gerald Lebovic, Yang Chen, Mary L'Abbé, Grace J. Lee, Jonathon L. Maguire, and TARGet Kids! Collaboration. 2017. "Association between Noncow Milk Beverage Consumption and Childhood Height." The American Journal of Clinical Nutrition 106 (2): 597-602. https://doi.org/10.3945/ajcn.117.156877

Schuster, Margaret J., Xinyue Wang, Tiffany Hawkins, and James E. Painter. 2018. "Comparison of the Nutrient Content of Cow's Milk and Nondairy Milk Alternatives: What's the Difference?" Nutrition Today 53 (4): 153-159. https://doi.org/10.1097/NT.0000000000000284

Silk. n.d. "Unsweet Cashewmilk." https://silk.com/plantbased-products/cashewmilk/unsweetened-cashewmilk/. Accessed 10 August 2020.
Singhal, Sarita, Robert D. Baker, and Susan S. Baker. 2017. "A Comparison of the Nutritional Value of Cow's Milk and Nondairy Beverages." Journal of Pediatric Gastroenterology and Nutrition 64 (5): 799-805. https://doi.org/10.1097/ MPG.0000000000001380

Soares, Denise Josino, Pedro Hermano Menezes de Vasconcelos, André Luiz Melo Camelo, Elisane Longhinotti, Paulo Henrique Machado de Sousa, and Raimundo Wilane de Figueiredo. 2013. "Prevalent Fatty Acids in Cashew Nuts Obtained from Conventional and Organic Cultivation in Different Stages of Processing." Food Science and Technology 33 (2): 265-270. https://doi.org/10.1590/ S0101-20612013005000050

United States Department of Agriculture (USDA). 2015. Dietary Guidelines for Americans 2015-2020. http://health. gov/dietaryguidelines/2015/guidelines/. Accessed 10 August 2020.

White, D. A.. n.d. "Food Fight: Almond Milk Vs. Cashew Milk." https://www.foodnetwork.com/healthyeats/2016/03/ food-fight-almond-milk-vs-cashew-milk. Accessed 10 August 2020. 
Table 1. Nutrient profile of cashew milk compared to fat-free, low-fat, and whole cow's milk.

\begin{tabular}{|c|c|c|c|c|}
\hline & $\begin{array}{c}\text { Unsweetened cashew milk } \\
\text { ( } 1 \text { cup) }\end{array}$ & $\begin{array}{l}\text { Fat-free skim milk } \\
\qquad(1 \text { cup) }\end{array}$ & $\begin{array}{l}\text { Low-fat milk ( } 1 \%) \\
\text { ( } 1 \text { cup) }\end{array}$ & $\begin{array}{l}\text { Whole milk } \\
\text { ( } 1 \text { cup) }\end{array}$ \\
\hline Energy (calories) & 25 & 83 & 102 & 150 \\
\hline Protein (g) & $<1$ & 8 & 8 & 8 \\
\hline Total fat (g) & 2 & 0 & 2.4 & 8 \\
\hline Saturated fat (g) & 0 & 0.1 & 1.5 & 4.5 \\
\hline Carbohydrate (g) & 1 & 12 & 12 & 12 \\
\hline Fiber $(g)$ & 0 & 0 & 0 & 0 \\
\hline Total sugars (g) & 0 & 12 & 12 & 12 \\
\hline Vitamin A (mcg) & 150 & 149 & 142 & 112 \\
\hline Vitamin B12 (mcg) & $N R$ & 1 & 1 & 1 \\
\hline Vitamin D (mcg) & 2.5 & 3 & 3 & 3 \\
\hline Calcium (mg) & 450 & 298 & 305 & 276 \\
\hline Sodium (mg) & 160 & 102 & 107 & 105 \\
\hline Potassium (mg) & 0 & 381 & 366 & 322 \\
\hline
\end{tabular}

